\title{
IMPLEMENTASI ETIKA BISNIS ISLAM DAN TRANSFORMASI DIGITAL UMKM MADURA DALAM MENDUKUNG KETERCAPAIAN SUSTAINABLE DEVELOPMENT GOALS
}

\author{
Nasrulloh \\ Universitas Trunojoyo Madura \\ e-mail: nasrulloh@trunojoyo.ac.id
}

\begin{abstract}
This study aims at capturing the types of MSMEs in Madura; identifying the suitability of sharia business ethics of MSMEs in Madura; and describing the marketing management of MSMEs in Madura for increasing sales value and competitiveness in the digital economy industry so that they are able to support the achievement of the Sustainable Development Goals (SDG's). Using a qualitative method with a literature study approach and in-depth interviews in field studies, the results of the study show that, in general, the portrait of MSME subject in Madura deals with the food industry of agricultural and marine products, herbal drinks and traditional herbs, as well as the wood carving manufacturing industry. and shipbuilding. As a society that has a high level of religiosity, some MSME subjects in Madura have implemented Islamic business ethics by processing halal certificates for their products. In order to increase marketing and sales of their products, they are familiar with the use of online marketplaces. They prefer to market their products offline or use personal social media and e-commerce accounts but are reluctant to join websites managed by the government. Changes in mindset and innovation, strengthening cooperation between parties and utilizing technological advances are strongly needed for the development and progress of MSME products in Madura. So that they are able to reach the global community and support the achievement of the Sustainable Development Goals (SDG's).
\end{abstract}

Keywords: MSME in madura; islamic business ethics; digital marketing; sustainable development goals (SDG's)

\section{Pendahuluan}

Perkembangan industri teknologi yang terus menerus bergerak mengakibatkan segala macam kegiatan harus ikut serta dalam pengaplikasiannya. Kegiatan perekonomian adalah salah satunya. Kegiatan semacam penjualan maupun produksi semakin dituntut untuk mampu memenuhi kebutuhan masyarakat yang serba cepat. Perkembangan teknologi informasi yang terjadi memunculkan istilah e-commerce, yaitu proses pembelian dan penjualan produk, jasa dan informasi yang dilakukan secara elektronik dengan menggunakan jaringan computer, dan jaringan yang digunakan adalah jaringan internet. ${ }^{1}$ Di Indonesia, digital marketing sudah sangat berkembang mengingat pengguna internet di Indonesia yang semakin meningkat. Berdasarkan Survey Global Web Index menyebutkan bahwa Indonesia sudah banyak melakukan kegiatan layanan jual beli secara online.

Mayoritas kegiatan masyarakat Indonesia didominasi oleh aktivitas konsumtif, nilai-

\footnotetext{
${ }^{1}$ Allastair M. Morrison, Periklanan Komunikasi Pemasaran Terpadu (Jakarta: Penerbit Kencana, 2010), 74.
} 
nilai daya beli masyarakat Indonesia sangat tinggi, yaitu berkisar 90-96\%, namun hal tersebut tidak diikuti dengan nilai produktivitas atau aktivitas jual sehingga antara konsumsi dan kegiatan produksi tidak berimbang. Besarnya minat masyarakat terhadap aktivitas jual beli secara online patut mendapat perhatian pemerintah sehingga UMKM dapat berkontribusi langsung di dalamnya. Peran dan andil UMKM dalam perekonomian nasional terbilang strategis bila diteropong dari jumlah unit usahanya yang mendominasi, tingginya penyerapan tenaga kerja, besarnya kontribusi dalam pembentukan produk domestik bruto (PDB) nasional dan sumbangannya terhadap nilai ekspor. Menurut Teten Masduki, potensi kekuatan UKM Indonesia bukan hanya sekadar angka kontribusi terhadap PDB yang sudah mencapai 60.23 persen dan jumlah pelaku melebihi 64 juta usaha. Terkait dengan pencapaian UMKM, target nilai ekspor produk UMKM dari pemerintah naik signifikan dari 14,5 persen menjadi 30 persen pada tahun 2024. ${ }^{2}$ Sehingga UMKM dalam hal ini memiliki peranan besar dalam meningkatkan pertumbuhan perekonomian Indonesia karena dengan banyaknya jumlah penduduk Indonesia, UMKM berperan untuk menambah lapangan pekerjaan. Namun demikian, faktanya belum ada inovasi yang berdaya saing bagi para pelaku industri UMKM, khususnya pada aktivitas ekonomi digital.

Sebagai salah satu identitas keislaman seorang pengusaha adalah proses dalam menjalankan usahanya. Pengusaha muslim seharusnya mampu mengimplementasikan nilainilai keislaman melalui etika bisnis islami. Salah satu indikator implementasi etika bisnis Islam adalah menjual produk halal. Pemerintah mengatur penjualan produk halal dengan diterbitkannya Undang-Undang Jaminan Produk Halal di mana setiap produk makanan olahan yang beredar di Indonesia arus mendapatkan sertifikasi halal. Prosedur ini semakin menguatkan citra bisnis islami dan menjadi nilai tambah sebuah produk. ${ }^{3}$

Munculnya ekonomi digital tentu mempengaruhi eksistensi industri perdagangan di Indonesia, seperti UMKM. Pengembangan UMKM yang didasarkan pada penerapan teknologi digital akan meningkatkan akses, pengelolaan, integrasi, analisis, dan evaluasi informasi sehingga mempermudah pertukaran informasi dan jaringan. Hal ini berdampak pada optimalisasi kinerja dan jangkauan organisasi UMKM berbasis digital demi menunjang keberpihakan kepada masyarakat luas. Misi tersebut akan sulit dicapai tanpa adanya interkoneksi nyata antar UMKM yang didukung peran vital pemerintah terkait sebagai bagian dari policy maker serta tentunya campur tangan stakeholder lain.

Peran penting UMKM dalam perekonomian nasional mencerminkan peran penting UMKM dalam pencapaian tujuan pembangunan berkelanjutan atau Sustainable Development Goals (SDG's) di Indonesia. UMKM dapat menjadi garda paling depan dalam pencapaian pilar ekonomi SDG's dengan penciptaan lapangan kerja, penciptaan kondisi kerja yang layak, inovasi bisnis, adaptasi dan mitigasi dampak negatif ekonomi, sosial dan lingkungan pada operasi bisnis untuk pertumbuhan ekonomi yang inklusif.

Penelitian ini berusaha memotret bagaimana pelaku UMKM di Madura menerapkan etika bisnis Islam dalam usahanya serta pola pemasaran yang memanfaatkan teknologi digital

\footnotetext{
2 Reynas Abdila, "Pemerintah Target Nilai Ekspor Produk UMKM Naik 30 Persen di 2024" dalam https://www.tribunnews.com/bisnis/2019/12/26/pemerintah-target-nilai-ekspor-produk-umkm-naik-30-persendi-2024, diakses pada 25 September 2020.

${ }^{3}$ Undang-Undang Nomor 33 Tahun 2014 tentang Jaminan Produk Halal.
} 
sehingga mampu membantu ketercapaian SDG's.

\section{Metode Penelitian}

Penelitian ini termasuk penelitian kualitatif dengan kajian lapangan. Abdurrahmat Fathoni menyebutkan bahwa penelitian lapangan merupakan penelitian yang dilakukan di lapangan atau di lokasi penelitian, suatu tempat yang dipilih sebagai lokasi untuk menyelidiki gejala objektif sebagai terjadi di lokasi tersebut yang dilakukan juga untuk penyusunan laporan ilmiah. ${ }^{4}$ Metode pengumpulan data dilakukan melalui penulusuran kepustakaan dan lapangan. Studi kepustakaan dilakukan dengan cara menganalisa buku-buku, analisa neraca bisnis, jurnal ekonomi dan bisnis dan website e-commerce yang memberikan input atau menunjang penelitian.

Studi lapangan ini dilakukan melalui studi dokumen dan studi lapangan. Studi dokumen untuk memperoleh informasi dalam bentuk laporan kegiatan tahun 2019. Dalam menentukan objek yang dijadikan sampel, penelitian ini menggunakan metode non probability sampling dengan teknik purposive sampling, yaitu melakukan pengambilan atau pemilihan sampel yang dilakukan hanya atas dasar pertimbangan penelitian saja yang menganggap unsur-unsur yang dikehendaki telah ada dalam anggota sampel yang diambil. Cara ini bertujuan untuk membangun sebuah pemahaman yang detail guna membantu peneliti memahami fenomena dan mengungkap rahasia yang terpendam. Selain melakukan analisis terhadap dokumen, penulis juga melakukan wawancara dengan Dinas UMKM. Dalam wawancara ini dilakukan dengan model wawancara bebas terpimpin, yaitu wawancara dengan daftar pertanyaan terlebih dahulu yang dipakai sebagai pedoman, tetapi variasi pertanyaan disesuaikan dengan situasi pada saat wawancara dilakukan dengan tujuan untuk memudahkan memperoleh data secara mendalam.

Analisis data menggunakan model Miles dan Huberman yang terdiri dari reduksi data, penyajian data, dan penarikan kesimpulan. ${ }^{5}$ Proses analisis data dimulai dengan penelusuran dokumen tentang UMKM. Langkah selanjutnya adalah melakukan wawancara terhadap informan untuk mendapatkan data terkait dengan sebaran UMKM di Madura, etika bisnis yang jalankan serta manajemen pemasaran atas bisnis UMKM di Madura.

\section{Ekonomi Digital}

Hartman dalam Amir ${ }^{6}$ mendefinisikan ekonomi digital sebagai the virtual arena in which business actually is conducted, value is created and exchanged, transactions occur, and one-to-one relationship mature by using any internet initiative as medium of exchange". Sedangkan konsep ekonomi digital lainnya adalah digitalisasi informasi dan infrastruktur TIK. Konsep ini sering digunakan untuk menjelaskan dampak global teknologi informasi dan komunikasi, tidak hanya pada internet, tetapi juga pada bidang ekonomi. Konsep ini menjadi sebuah pandangan tentang interaksi antara perkembangan inovasi dan kemajuan teknologi dan dampaknya pada ekonomi makro maupun ekonomi mikro. ${ }^{7}$

\footnotetext{
${ }^{4}$ Abdurrahmat Fathoni, Metodologi Penelitian \& Teknik Penyusunan Skripsi (Jakarta: Rineka Cipta, 2011$), 62$.

${ }^{5}$ M. B. Milles dan M. A. Huberman, Qualitative Data Analysis (London: Sage Publication, 1984), 82.

${ }^{6}$ M. Amir, Net Ready: Strategies for Success in the Economy (New York: McGraw-Hill, 2000), 126.

7 Aan Ansori, "Digitalisasi Ekonomi Syariah," Jurnal Islamiconomic: Jurnal Ekonomi Keuangan dan Bisnis Islam, Volume 7, Nomor 1 (2016), 1-18.
} 
Ekonomi digital merupakan ekonomi yang didasarkan pada barang dan jasa yang dihasilkan oleh perangkat elektronik dan diperdagangkan melalui perdagangan elektronik. Artinya, bisnis ini mempunyai kaitan dengan produksi elektronik dan proses manajemen yang berhubungan dengan mitra yang dilakukan melalui transaksi internet ataupun teknologi website. The Nielsen Global Survey of E-Commerce mensurvei responden yang memiliki akses internet di 60 negara untuk mempelajari intensitas belanja online dari konsumen di seluruh dunia. Studi ini memberikan kejelasan mengenai intensi konsumen untuk membeli baik barang yang habis digunakan maupun yang tidak habis digunakan dalam lanskap $e$ commerce yang sedang tumbuh. ${ }^{8}$

Pengertian digital economy lebih menitikberatkan pada proses jual beli atau transaksi dan pasar yang terjadi di dunia maya. Ekonomi digital adalah suatu sistem ekonomi yang kompleks dan merupakan fenomena yang baru muncul terkait dengan aspek-aspek ekonomi mikro, ekonomi makro, dan teori organisasi dan administrasi. Sedangkan konsep digital marketing berasal dari internet dan search engines pada situs. Ketika penggunaan internet meledak di tahun 2001, pasar didominasi oleh Google dan Yahoo sebagai search engine optimization (SEO). Penggunaan pencarian melalui internet berkembang pada tahun 2006 dan pada tahun 2007 penggunaan perangkat mobile meningkat drastis yang juga meningkatkan penggunaan internet dan masyarakat dari berbagai penjuru dunia mulai berhubungan satu sama lain melalui media sosial. ${ }^{9}$

\section{Pemasaran Digital}

American Marketing Association (AMA) mendefinisikan digital marketing sebagai aktivitas, institusi, dan proses yang difasilitasi oleh teknologi digital dalam menciptakan, mengomunikasikan, dan menyampaikan nilai-nilai kepada konsumen dan pihak yang berkepentingan lainnya. ${ }^{10}$ Sanjaya menyebutkan bahwa pemasaran digital merupakan kegiatan marketing, termasuk branding yang memanfaatkan bermacam media berbasis web. ${ }^{11}$ Sedangkan menurut Ali, pemasaran digital merupakan upaya pemanfaatan dari teknologi digital dalam mencapai tujuan pemasaran serta upaya pengembangan atau penyesuaian konsep pemasaran itu sendiri, dapat berkomunikasi dalam cakupan global, dan mengubah bagaimana sebuah perusahaan melakukan komunikasi bisnis dengan para pelanggannya. ${ }^{12}$ Lebih lanjut, sejatinya pemasaran digital merupakan suatu proses pemasaran yang menggunakan teknologi komunikasi elektronik, khususnya internet. Peran strategi pemasaran digital dapat menjadi hal yang penting dalam mengikuti perkembangan teknologi digital dan mengembangkan rencana untuk menarik konsumen dan mengarahkannya pada perpaduan antara komunikasi elektornik dan komunikasi tradisional. ${ }^{13}$

\footnotetext{
${ }^{8}$ Arief Iman Santoso, dkk, "Kesiapan UMKM Industri Kreatif Kota Surakarta dalam Menghadapai Masyarakat Ekonomi Digital (Digital Economy Ecosystem)," Prosiding SENADIMAS, Volume 2 (2017), 152.

${ }^{9}$ A. Khan, et al, "Corporate Governance and Corporate Social Responsibility Disclosures: Evidence from an Emerging Economy," Journal of Business Ethics, Volume 8, Nomor 2 (2013), 183.

${ }^{10}$ P. K. Kannan dan L. Hongshuang, "Digital Marketing: A Framework, Review and Research Agenda," International Journal of Research in Marketing, Volume 34, Nomor 1 (2016), 93.

${ }^{11}$ R. Sanjaya dan J. Tarigan, Creative Digital Marketing (Jakarta: Elex Media Komputindo, 2009), 88.

${ }^{12}$ H. Ali, Marketing dan Kasus-Kasus Pilihan (Yogyakarta: CAPS, 2013), 59

${ }^{13}$ D. Chaffey, et al, Internet Marketing: Strategy, Implementation, and Practice (United States: Prentice Hall, 2009), 164.
} 
Strategi pemasaran digital berpengaruh hingga 78 persen terhadap keunggulan bersaing UMKM dalam memasarkan produknya. Strategi tersebut terdiri dari ketersediaan informasi produk dan panduan produk; ketersediaan gambar-gambar seperti foto atau ilustrasi produk; ketersediaan video yang mampu memvisualisasikan produk atau menampilkan presentasi pendukung; ketersediaan lampiran dokumendokumen yang berisi informasi dalam berbagai format; ketersediaan komunikasi online dengan pengusaha; ketersediaan alat transaksi dan variasi media pembayaran; ketersediaan bantuan dan layanan konsumen; ketersediaan dukungan opini online; ketersediaan tampilan testimonial; ketersediaan catatan pengunjung; ketersediaan penawaran khusus; ketersediaan sajian informasi terbaru melalui SMS-blog; kemudahan pencarian produk; kemampuan menciptakan visibilitas dan kesadaran merek; kemampuan mengidentifikasi dan menarik pelanggan baru; kemampuan penguatan citra merek yang diterima oleh konsumen.

Pemanfaatan pemasaran digital memiliki beberapa keunggulan, antara lain target bisa diatur sesuai demografi, domisili, gaya hidup, dan bahkan kebiasaan; hasil cepat terlihat sehingga pemasar dapat melakukan tindakan koreksi atau perubahan apabila dirasa ada yang tidak sesuai; biaya jauh lebih murah daripada pemasaran konvensional; jangkauan lebih luas karena tidak terbatas geografis; dapat diakses kapanpun tidak terbatas waktu; hasil dapat diukur, misalnya jumlah pengunjung situs, jumlah konsumen yang melakukan pembelian online; kampanye bisa dipersonalisasi; bisa melakukan engagement atau meraih konsumen karena komunikasi terjadi secara langsung dan dua arah sehingga pelaku usaha membina relasi dan menumbuhkan kepercayaan konsumen. ${ }^{14}$

\section{Etika Bisnis Islam}

Nabi Muhammad telah memberikan teladan etika dalam menjalankan bisnis. Beberapa panduan berbisnis di antaranya adalah pertama, mengamalkan nilai-nilai kejujuran. Dalam salah satu hadis yang diriwayatkan oleh al-Quzwani, Nabbi bersabda bahwa tidak dibenarkan seorang muslim menjual satu jualan yang mempunyai aib kecuali ia menjelaskan aibnya. Kedua, mengimplementasikan sikap ta'äwun (saling menolong). Pelaku bisnis menurut Islam tidak hanya sekedar mengejar keuntungan sebanyak-banyaknya namun juga berorientasi kepada kebaikan dengan cara menyediakan barang atau jasa bagi yang membutuhkan. Ketiga, tidak melakukan kecurangan. Allah berfirman bahwa celakalah bagi orang yang curang, yaitu orang yang apabila menerima takaran dari orang lain, mereka minta dipenuhi, dan apabila mereka menakar atau menimbang untuk orang lain, mereka mengurangi. ${ }^{15}$ Keempat, tidak mempromosikan usahanya dengan menjatuhkan usaha orang lain. Nabi Muhammad bersabda bahwa janganlah seseorang di antara kalian menjual dengan maksud untuk menjelekkan apa yang dijual oleh orang lain. Kelima, tidak menumpuk dan menyimpan barang dalam masa tertentu dengan tujuan agar mendapatkan keuntungan besar saat harga barang naik, sebagaimana sabda Rasulullah bahwa tidak akan menimbun kecuali orang berbuat dosa. (HR. Muslim).

\footnotetext{
${ }^{14}$ Aditya Wardhana, "Strategi Digital Marketing dan Implikasinya Pada Keunggulan Bersaing UMK di Indonesia," Seminar Nasional Keuangan dan Bisnis, Universitas Pendidikan Indonesia, Bandung pada April 2015.

15 al-Quran, 83:112.
} 
Keenam, tidak melakukan monopoli. al-Syirbiny menjelaskan keharaman praktik monopoli, bahwa haram melakukan monopoli karena niat menyulitkan orang banyak. ${ }^{16}$ Ketujuh, hanya menjual barang yang suci dan halal. Nabi Muhammad bersabda bahwa sesungguhnya Allah mengharamkan bisnis miras, bangkai, babi dan patung-patung. (H.R. Jabir). Kedelapan, tidak melakukan riba dalam berbisnis. Kesembilan, Menjalani bisnis tanpa paksaan. Kesepuluh, adil terhadap pegawai.

\section{Sustainable Development Goals (SDG's)}

Tujuan pembangunan berkelanjutan atau sustainable development goals (SDG's), juga dikenal sebagai tujuan global, diadopsi oleh semua negara anggota Perserikatan BangsaBangsa pada tahun 2015 sebagai seruan universal untuk bertindak untuk mengakhiri kemiskinan, melindungi planet ini dan memastikan bahwa semua orang menikmati perdamaian dan kemakmuran pada tahun 2030. Melalui komitmen untuk "None Left Behind", negara-negara telah berkomitmen untuk mempercepat kemajuan bagi mereka yang terbelakang terlebih dahulu. Kreativitas, pengetahuan, teknologi, dan sumber daya keuangan dari seluruh masyarakat diperlukan untuk mencapai SDG's dalam setiap aspek. SDG's mendorong pertumbuhan ekonomi yang berkelanjutan, tingkat produktivitas dan inovasi teknologi yang lebih tinggi. Mendorong kewirausahaan dan penciptaan lapangan kerja adalah kunci untuk ini, seperti juga langkah-langkah efektif untuk memberantas kerja paksa, perbudakan dan perdagangan manusia. Dengan mengingat target-target ini, tujuannya adalah untuk mencapai pekerjaan layak dan produktif, dan pekerjaan yang layak, untuk semua perempuan dan laki-laki pada tahun 2030 .

\section{Selayang Pandang UMKM di Madura}

Masyarakat Madura dalam menjalankan roda perekonomiannya melalui usaha mikro kecil terbagi dari berbagai sektor, di antaranya produk makanan, kain batik, kayu ukir dan kerajinan tangan. Klusterisasi produk-produk tersebut terbagi atas perbedaan wilayah yang ada di Madura. Di Sumenep dan Bangkalan, pengembangan produk makanan lebih menonjol dibandingkan kabupaten lain dikarenakan wilayah tersebut berada di daerah pesisir yang memudahkan dalam persediaan bahan baku, seperti lorjuk, udang, ikan dan lain sebagainya yang nantinya akan diolah menjadi berbagai makanan, seperti rengginang lorjuk, petis gurih dan pedas, keripik dan lain sebagainya. Berbeda halnya dengan wilayah Pamekasan dan Sampang yang menonjolkan kerajinan tangan dan batik yang menjadi produk unggulannya. Kain batik yang menjadi ikon dua kabupaten tersebut diklaim memiliki kombinasi warna yang cerah, seperti hijau, merah dan kuning.

Usaha mikro kecil di wilayah Madura diatur oleh Dinas Koperasi dan UMK dan Dinas Perindustrian dan Perdagangan. Hanya saja ada pembagian yang jelas selain modal, yaitu wilayah. Dinas Perindustrian fokus kepada sosialisasi kepada pelaku usaha untuk menjalankan usaha industri rumahan tanpa ada minimal modal, sedangkan Dinas Koperasi mengatur pelaku usaha dengan kisaran modal kurang dari 100 juta. ${ }^{17}$

16 Syamsudin Muhammad ibn Ahmad Al-Khathib al-Syirbiny, Mughny al-Muhtaj, juz 2 (Beirut: Dar alMa'rifah, 1997), 7.

${ }^{17}$ Ahmad Muchlas, Wawancara, Bangkalan, 12 Agustus 2020. 
Tabel 1.1. Data UKM Binaan Pemerintah Daerah Madura

\begin{tabular}{|c|l|c|c|c|c|c|}
\hline No. & \multicolumn{1}{|c|}{ Jenis IKM } & Bangkalan & Sampang & Pamekasan & Sumenep & Jumlah \\
\hline 1. & Olahan makanan & 27 & 19 & 53 & 110 & 209 \\
\hline 2. & Minuman tradisional dan jamu & 5 & 4 & 5 & - & 14 \\
\hline 3. & Konveksi & 3 & 3 & 6 & 3 & 15 \\
\hline 4. & Furnitur kayu & - & 1 & 10 & 31 & 42 \\
\hline 5. & Beton dan logam & - & - & 6 & 5 & 11 \\
\hline 6. & Pembuatan kapal & - & - & - & 1 & 1 \\
\hline 7. & Pengolahan garam & - & - & 3 & - & 3 \\
\hline 8. & Penggilingan padi & - & - & 2 & - & 2 \\
\hline 9. & Kretek & - & - & 37 & - & 37 \\
\hline 10. & Pengkomposan dan pupuk & - & - & 1 & - & 1 \\
\hline & Total & 35 & 27 & 123 & 150 & 335 \\
\hline
\end{tabular}

Sumber: data Dinas Koperasi dan UMK dan Dinas Perindustrian dan Perdagangan Madura

Berdasarkan tabel tersebut ${ }^{18}$ dapat disimpulkan bahwa mayoritas produk industri kecil dan mikro di wilayah Kabupaten Bangkalan mayoritas didominasi oleh produk olahan makanan, seperti keripik, kerupuk, abon, dan kue kering, disusul kemudian olahan herbal, seperti bubuk jahe merah, minyak kelapa dan minuman jamu tradisional. Dari tabel tersebut dapat dinyatakan jika industri kecil menengah lebih banyak dan beragam jenisnya dan industri olahan makanan mendominasi industri Sumenep, hal ini dikarenakan bahan baku ikan yang melimpah dimanfaatkan oleh masyarakat setempat dengan mengolahnya menjadi produk kudapan yang lezat dan menarik konsumen, seperti kerupuk, keripik, petis, kue kering dan industri tahu. Kemudian disusul oleh industri furniture yang diolah dari bahan baku kayu untuk menjadi mebel dan lain sebagainya, disusul kemudian industri beton dan logam yang digunakan untuk pembuatan teralis besi, pilar, pagar, kanopi dan peralatan perahu. Sedangkan untuk industri konveksi dan pembuatan kapal masih sedikit berkisar 1-3 industri dari seluruh jumlah industri yang ada di Kabupaten Sumenep.

Tidak jauh berbeda dengan dua kabupaten sebelumnya, produk olahan makanan baik yang berasal dari pertanian ataupun olahan dari laut juga didominasi oleh Kabupaten Pamekasan dan Sampang. Produk olahan makanan di Kabupaten Pamekasan ditonjolkan dari berbagai macam kerupuk, keripik, peyek dan sejenisnya, roti, kue basah dan kering, produk olahan tahu dan tempe kedelai, bumbu masuk dan penyedap makanan, kecap, pengolahan garam, teh, dan kopi. Selain dari produk olahan makanan, di kabupaten Pamekasan juga jamak ditemukan industri kretek, rokok, pengolahan dan pengeringan tembakau. Hal ini dikarenakan Kabupaten Pamekasan adalah salah satu daerah penghasil tembakau terbesar di Madura dengan luas lahan mencapai 31.251 hektare yang tersebar di 13 kecamatan. Sebagian besar tembakau di Pulau Madura diserap oleh pabrik rokok sebagai bahan baku utama rokok maupun sebagai racikan atau campuran kretek. Hasil tembakau Kabupaten Pamekasan

\footnotetext{
${ }^{18}$ Data dalam tabel tersebut merupakan data yang didapatkan dari hasil wawancara dengan Dinas Koperasi dan UMK dan Dinas Perindustrian dan Perdagangan. Beberapa dinas tidak memberikan data secara lengkap serta beberapa UMKM yang tidak terdata di database Dinas terkait menyebabkan data yang disajikan tersebut bisa saja berbeda dengan jumlah existing pelaku UMKM di Madura.
} 
merupakan salah satu tembakau terbaik yang dimiliki Indonesia. ${ }^{19}$ Selain produk-produk industri tersebut, Kabupaten Pamekasan juga menjadi salah satu kabupaten di Indonesia penghasil garam sebagaimana kabupaten lain di Madura seperti Sumenep dan Sampang. Menurut data tahun 2018, Kabupaten Sampang menjadi kabupaten penghasil garam terbesar di Indonesia dengan total produksi 312.061 ton. Capaian tersebut mengalahkan Kabupaten Indramayu di urutan kedua dengan hasil produksi 285.242 ton garam. Sehingga tidak heran jika pulau Madura dikenal dengan julukan pulau garam. ${ }^{20}$

Sebagai penghasil garam terbesar di Pulau Madura, Kabupaten Sampang juga memiliki industri olahan makanan yang berasal dari laut, seperti berbagai macam jenis kerupuk ikan, kerupuk udang, cumi dan ikan teri krispi, berbagai macam jenis bumbu petis dan abon, berbagai macam jenis roti kue kering dan basah, kacang mete, pengrajin songkok tenun dan anyaman bambu, dompet, tas dan batik serta industri minuman herbal tradisional dengan bahab baku berkualitas khas Madura yang telah tersebar di beberapa wilayah di Indonesia, seperti seluruh pulau Madura, Jakarta, Lampung, Batam dan Balikpapan.

\section{Implementasi Etika Bisnis Islam pada UMKM Madura}

Dinas Perindustrian, Perdagangan, dan Tenaga Kerja (Disperindagker) Bangkalan menaungi dua Asosiasi UMKM, yaitu "Kuda Terbang" dan "Perwira". Asosiasi UMKM Perwira (Perempuan Wirausaha) di Bangkalan merupakan organisasi tingkat daerah dari asosiasi yang sama di tingkat nasional. Asosiasi UMKM Kuda Terbang di bawah Disperindagker Bangkalan beranggotakan 120 pelaku UMKM.

Salah satu indikator pelaksanaan etika bisnis Islam dalam berbisnis adalah menjual produk halal. Pemerintah mengatur peredaran produk makanan olahan di Indonesia melalui Undang-Undang Jaminan Produk Halal. Seluruh produk makanan olahan harus tersertifikasi halal dengan prosedur yang sudah ditentukan oleh undang-undang. Fahrizal Emir memberikan keterangan yang berbeda terkait pendaftaran sertifikat halal produk pangan produksinya. Produk Teri Crispy N-4 yang mulai diproduksi sejak tahun 2018 dan kini sudah memiliki pasar nasional hingga Singapura telah melaksanakan proses audit mutu dalam rangka pengajuan sertifikasi halal. Fahrizal menyatakan, dalam proses pengembangan produknya, banyak informasi yang didapatkan dari asosiasi UMKM yang dinaungi oleh Disperindagker Bangkalan. Pendaftaran sertifikasi halal produknya pun difasilitasi oleh Disperindagker Bangkalan sehingga pelaku usaha tidak perlu mengeluarkan biaya sepeserpun. ${ }^{21}$

Bagi fahrizal, sebuah produk perlu memiliki nilai jual lebih agar dapat bersaing di pasar bebas, salah satunya adalah memiliki sertifikat halal. Indonesia sebagai negara dengan konsumen mayoritas muslim, produk pangan berlabel halal dirasa penting sebagai bagian dari proses penyelenggaraan perlindungan konsumen karena prosedur mendapatkan label halal telah melewati berbagai uji mutu sehingga pasti aman dikonsumsi oleh konsumen muslim. ${ }^{22}$

\footnotetext{
${ }^{19}$ Nurhadi, "Daerah Penghasil Tembakau Terbaik di Indonesia” dalam https://bisnis.tempo.co/read/1513782/5daerah-penghasil-tembakau-terbaik-diindonesia/full\&view=ok, diakses pada 10 November 2021.

20 Muhammad Choirul Anwar, "Dijuluki Pulau Garam Ini Hasil Produksi Garam di Madura" dalam https://money.kompas.com/read/2021/03/22/145029326/dijuluki-pulau-garam-ini-hasil-produksi-garam-dimadura?page $=$ all, diakses pada 10 November 2021 .

${ }^{21}$ Fahrizal Emir, Wawancara, Bangkalan, 11 September 2020.

${ }^{22}$ Ibid.
} 
Proses pendaftaran, kunjungan auditor, hingga mendapatkan sertifikat halal hanya membutuhkan waktu kurang lebih tiga bulan. Keengganan pelaku usaha untuk mendaftarkan sertifikasi halal bagi produknya hanya karena mindset yang sudah terbangun bahwa prosedur ini akan sulit, mahal, dan memakan waktu lama. Pemerintah perlu menggandeng UMKM yang sudah memiliki sertifikat halal bagi produknya untuk memberikan bantuan dan panduan bagi pelaku UMKM lain sehingga termotivasi untuk mengikuti jejak pengajuan sertifikat halal

\section{Strategi Pemasaran Produk UMKM Madura}

Strategi pemasaran merupakan suatu mindset pemasaran yang akan digunakan untuk mencapai tujuan pemasaran yang di dalamnya terdapat strategi rinci mengenai pasar sasaran, penetapan posisi, bauran pemasaran, dan budget untuk pemasaran. ${ }^{23}$ Melihat dari potret produk UMKM Madura yang beragam, banyak dari para pelaku UMKM belum menggunakan strategi pemasaran yang jelas dan tidak memperhatikan bauran pemasaran. Hal ini dikarenakan masih banyaknya pelaku UMKM di Madura yang menggunakan metode konvensional dalam memasarkan produknya, yaitu dengan membuka usahanya dengan menggunakan toko, gerobak maupun media yang lain.

Selama pandemi covid-19 melanda, kebijakan daerah sedikit banyak mempengaruhi gerak pelaku usaha dalam menjalankan bisnisnya. Pelaku UMKM dituntut untuk kreatif dan inovatif dalam menyusun strategi pemasarannya. Salah satu dari sekian banyak alternatif yang paling banyak diminati oleh para pelaku UMKM Madura adalah menggunakan marketplace atau jual beli dengan sistem online. Sebagaimana yang disampaikan oleh Kepala Dinas Perindustrian dan Perdagangan Sumenep dan Sampang bahwa sebagian pelaku UMKM sudah melakukan penjualan online dengan akun marketplace pribadi, ${ }^{24}$ seperti Shopee, Lazada, Bukalapak dan Tokopedia. ${ }^{25}$ Sedangkan di Pamekasan, para pelaku UMKM menggunakan media soaial untuk promosi produknya, seperti Instagram, WhatsApp, Facebook dan lain sebagainya. ${ }^{26}$ Berbeda halnya dengan tiga kabupaten di Madura tersebut, di Kabupaten Bangkalan mayoritas masih didominasi oleh penjual offline, seperti toko, gerobak, maupun dengan cara keliling. ${ }^{27}$

Berbeda halnya dengan wilayah lain di Madura yang mayoritas pelaku usaha UMKMnya masih menggunakan akun pribadi dan dengan inisiatif sendiri membuka toko online di marketplace maupun sosial media mainstream, Dinas Koperasi dan UMKM di Kabupaten Sumenep telah membuat marketplace resmi yang langsung dikelola oleh pemerintah setempat guna memfasilitasi kegiatan promosi dan penjualan secara online pelaku UMKM di wilayahnya. Oleholehsumenep.com telah berfungsi baik dan dimanfaatkan oleh beberapa pelaku UMKM yang fokus pada penjualan souvenir dan oleh-oleh khas Kabupaten Sumenep.

Beragamnya bahan baku yang tersedia dan mudah diperoleh di Madura, seperti kerang, lorjuk, teripang dan produk olahan laut lainnya seharusnya menjadi peluang pengembangan

\footnotetext{
${ }^{23}$ Philip Kottler dan Kevin Lane Keller, Manajemen Pemasaran, edisi 13, jilid 1 (Jakarta: Penerbit Erlangga, 2010), 117.

${ }^{24}$ Suci Prawira Sari, Wawancara, Sumenep, 24 Agustus 2020.

${ }^{25}$ Muhamad Irwan Ferdiawan, Wawancara, Sampang, 22 Agustus 2020.

${ }^{26}$ Abdiyati Muradi, Wawancara, Pamekasan, 3 Agustus 2020.

${ }^{27}$ Abdul Karim, Wawancara, Bangkalan, 27 Agustus 2020.
} 
produk menjadi berbagai penganan olahan maupun produk makanan lainnya. Madura yang merupakan salah satu daerah tujuan wisata religi dan wisata alam juga menjadi peluang dalam peningkatan penjualan produk. Promosi dan penjualan secara online melalui marketplace maupun sosial media menjadi alat yang cocok untuk menjangkau konsumen yang lebih luas, nasional bahkan internasional.

Namun demikian, keengganan masyarakat dalam melakukan sebuah inovasi hasil alam dinilai kurang. Pelaku UMKM cenderung pasif dan sulit untuk diajak maju. Karim mengatakan bahwa Disperindagker Bangkalan sendiri sudah banyak melakukan sosialisasi langsung ke masyarakat (Jawa: blusukan), tapi minat masyarakat masih kurang. Padahal hasil produk mereka bagus dan memiliki banyak potensi, seperti kacang di wilayah Socah tidak kalah dengan produk-produk yang sudah merambah nasional. Tapi kesadaran masyarakat yang sulit diajak untuk maju. Disperindagker Bangkalan menawarkan pelatihan agar mampu menaikan inovasi produk, seperti pelatihan packaging dan beberapa agenda lain. Namun mereka kurang berminat, tidak antusias dan mereka merasa sudah cukup dengan apa yang didapat. $^{28}$

Alasan menurut beberapa pelaku UMKM mengaku produk yang sudah ada sudah cukup baik terjual di lingkungan sekitarnya walaupun tidak dilakukan pengembangan produk. Sehingga pelaku UMKM sudah berada pada titik comfort zone. Fakta lain ditemukan jika para pelaku UMKM mengalami kesulitan pendaftaran dan pengurusan izin membuat beberapa pelaku UMKM tidak mau mengurus dokumen tersebut. Hal itu juga yang membuat pelaku UMKM lebih nyaman melakukan penjualan secara offline. Padahal Disperindagker Bangkalan sudah memfasilitasi pendaftaran tanpa dipungut biaya, bahkan memberikan subsidi 50 persen untuk biaya PIRTnya dan dibantu sampai selesai. ${ }^{29}$

Berdasarkan pemaparan tersebut, masih ada poin yang belum terintegrasi dengan baik antara dinas dan pelaku UMKM. Dari sisi lain, tantangan yang masih dihadapi oleh dinas selain inovasi produk dan simpang siurnya mengurus perizinan terkait PIRT adalah mengurus perizinan terkait label halal, uji laboratorium maupun izin edar lainnya.

\section{Digitalisasi Produk UMKM Mendukung Ketercapaian Sustainable Development Goals (SDGs')}

Dalam kurun waktu kurang dari lima tahun terakhir, pesatnya isu Sustainable Development Goals (SDG's) kerap muncul sebagai primadona di berbagai topik utama berita nasional maupun forum diskusi ilmiah di Indonesia. Bertempat di markas PBB pada tahun 2015, para pemimpin dunia secara resmi mengesahkan agenda Sustainable Development Goals (SDG's) sebagai kesepakatan pembangunan global. Tidak kurang dari 193 kepala negara hadir, termasuk Indonesia yang diwakili oleh Jusuf Kalla selaku wakil presiden yang turut mengesahkan agenda SDG's tersebut. Sebagai wujud komitmen politik pemerintah untuk melaksanakan SDG's, Presiden Jokowi telah menandatangani Peraturan Presiden SDG's Nomor 59 Tahun 2017 tentang Pelaksanaan Pencapaian Tujuan Pembangunan Berkelanjutan. Perpres tersebut juga merupakan komitmen agar pelaksanaan dan pencapaian SDG's dilaksanakan secara partisipatif dengan melibatkan seluruh pihak termasuk masyarakat

\footnotetext{
${ }^{28}$ Ibid.

${ }^{29}$ Ibid.
} 
sipil pada umumnya. ${ }^{30}$

Program SDG's merupakan aksi global yang dimulai dari tahun 2016 hingga 2030 yang memiliki misi khusus yang terdiri dari 17 tujuan dan 169 target. Dari 17 tujuan tersebut, beberapa yang menjadi poin utama pada topik penelitian ini adalah pemerataan dalam mengakhiri angka kemiskinan dan kelaparan, mendukung kesejahteraan bagi semua, memastikan keberlangsungan ekonomi dan mendukung kemitraan global untuk pembangunan yang berkelanjutan. Pada poin tujuan yang pertama, yaitu pemerataan dalam mengakhiri kemiskinan dan kelaparan, pada digitalisasi produk UMKM Madura mayoritas memang masih terbatas pada metode konvensional, belum sepenuhnya merata, namun demikian beberapa pelaku UMKM sudah menggunakan platform atau marketplace untuk memasarkan produknya khususnya produk olahan makanan. Sehingga hal tersebut dinilai mampu mendukung ketercapaian SDG's.

Dengan mulainya dukungan pemerintah daerah terhadap adanya digitalisasi produk UMKM baik yang dengan membuatkan marketplace ataupun menjadi pihak ketiga dalam menjembatani pelaku UMKM dengan marketplace, maka hal tersebut merupakan langkah awal yang baik dalam mendukung ketercapaian dari SDG's pada poin tujuan yang kedua dan ketiga, yaitu memastikan keberlangsunang ekonomi dan mendukung kemitraan global untuk pembangunan yang berkelanjutan. Pada poin tujuan yang terakhir, yaitu mendorong kesejahteraan bagi semua dapat dilakukan dan diupayakan dari sinergitas kegiatan tersebut di atas dan awareness dari para pelaku UMKM dalam menjalankan usahanya. Kesadaran yang dimaksud adalah bagaimana pelaku UMKM dapat berbenah diri dalam melakukan perubahan atau pengembangan produknya dan berkenan menerima perubahan atas kemajuan zaman agar mampu meningkatkan kesejahteraan ekonomi dan upaya ekspansi produk unggulan yang bernilai ekonomis dan berdaya saing secara global.

\section{Kesimpulan}

Mayoritas pelaku UMKM di Madura menggeluti usaha dalam bidang makanan olahan dan telah familiar dalam penggunaan marketplace berbasis online dalam upaya meningkatkan pemasaran dan penjualan produknya. Secara praktis, pelaku UMKM lebih nyaman mempromosikan usahanya melalui akun marketplace maupun media sosial pribadi dan tidak terkoneksi dengan website marketplace yang dikelola oleh pemerintah daerahnya. Berbeda dengan Kabupaten Sumenep yang sudah memiliki platform jual beli online produk UMKM, Kabupaten Sampang, Pamekasan, dan Bangkalan terkendala di penganggaran sehingga pemerintah daerah belum bisa menyediakan platform untuk mewadahi pelaku UMKM di daerah masing-masing. Pada aspek implementasi etika bisnis Islam, sikap jujur, saling menolong, tidak curang dan anti monopoli sudah diterapkan namun pelaku UMKM merasa keberatan dalam melakukan sertifikasi halal pada produk makanan olahan yang mereka jual. Pemerintah daerah perlu memperluas jangkauan sosialisasi dan pemberian hibah pengajuan proses sertifikasi halal sehingga lebih banyak pelaku UMKM yang mendapatkan sertifikat halal untuk produknya. Pemasaran produk melalui platform digital dan kepemilikan sertifikat

${ }^{30}$ Nasrulloh, "Filantropi Islam: Praktek dan Kontribusinya terhadap Ketercapaian Sustainable Development Goals (SDG's)," Proceedings $3^{\text {rd }}$ Annual Conference for Muslim Scholars (AnCoMs) Kopertais Wilayah IV Surabaya, Volume 3, Nomor 1 (2019), 364-375. 
halal pada produk UMKM dianggap mampu meningkatkan penjualan dan menjadi unique selling point sehingga dapat membantu ketercapaian Sustainable Development Goals (SDG's) pada aspek-aspek tertentu.

\section{Daftar Pustaka}

Morrison, Allastair M. Periklanan Komunikasi Pemasaran Terpadu. Jakarta: Penerbit Kencana, 2010.

Abdila, Reynas. "Pemerintah Target Nilai Ekspor Produk UMKM Naik 30 Persen di 2024" dalam https://www.tribunnews.com/bisnis/2019/12/26/pemerintah-target-nilai-eksporproduk-umkm-naik-30-persen-di-2024, diakses pada 25 September 2020.

Undang-Undang Nomor 33 Tahun 2014 tentang Jaminan Produk Halal.

Fathoni, Abdurrahmat. Metodologi Penelitian \& Teknik Penyusunan Skripsi. Jakarta: Rineka Cipta, 2011.

Milles, M. B. dan M. A. Huberman, Qualitative Data Analysis. London: Sage Publication, 1984.

Amir, M. Net Ready: Strategies for Success in the Economy. New York: McGraw-Hill, 2000.

Ansori, Aan. "Digitalisasi Ekonomi Syariah," Jurnal Islamiconomic: Jurnal Ekonomi Keuangan dan Bisnis Islam, Volume 7, Nomor 1 (2016).

Santoso, Arief Iman, dkk. "Kesiapan UMKM Industri Kreatif Kota Surakarta dalam Menghadapai Masyarakat Ekonomi Digital (Digital Economy Ecosystem)," Prosiding SENADIMAS, Volume 2 (2017).

Khan, A. et al. "Corporate Governance and Corporate Social Responsibility Disclosures: Evidence from an Emerging Economy," Journal of Business Ethics, Volume 8, Nomor 2 (2013).

Kannan, P. K. dan L. Hongshuang. "Digital Marketing: A Framework, Review and Research Agenda," International Journal of Research in Marketing, Volume 34, Nomor 1 (2016).

Sanjaya, R. dan J. Tarigan. Creative Digital Marketing. Jakarta: Elex Media Komputindo, 2009.

Ali, H. Marketing dan Kasus-Kasus Pilihan. Yogyakarta: CAPS, 2013.

Chaffey, D. et al. Internet Marketing: Strategy, Implementation, and Practice. United States: Prentice Hall, 2009.

Wardhana, Aditya. "Strategi Digital Marketing dan Implikasinya Pada Keunggulan Bersaing UMK di Indonesia," Seminar Nasional Keuangan dan Bisnis, Universitas Pendidikan Indonesia, Bandung pada April 2015.

al-Syirbiny. Syamsudin Muhammad ibn Ahmad Al-Khathib. Mughny al-Muhtaj, juz 2. Beirut: Dar al-Ma'rifah, 1997.

Muchlas, Ahmad. Wawancara. Bangkalan pada 12 Agustus 2020.

Nurhadi. "Daerah Penghasil Tembakau Terbaik di Indonesia" dalam https://bisnis.tempo.co/read/1513782/5-daerah-penghasil-tembakau-terbaikdiindonesia/full\&view=ok, diakses pada 10 November 2021.

Anwar, Muhammad Choirul. "Dijuluki Pulau Garam Ini Hasil Produksi Garam di Madura" dalam https://money.kompas.com/read/2021/03/22/145029326/dijuluki-pulau-garamini-hasil-produksi-garam-di-madura?page=all, diakses pada 10 November 2021 . 
Emir, Fahrizal. Wawancara. Bangkalan pada 11 September 2020.

Kottler, Philip dan Kevin Lane Keller. Manajemen Pemasaran, edisi 13, jilid 1. Jakarta: Penerbit Erlangga, 2010.

Sari, Suci Prawira. Wawancara. Sumenep pada 24 Agustus 2020.

Ferdiawan, Muhamad Irwan. Wawancara. Sampang pada 22 Agustus 2020.

Muradi, Abdiyati. Wawancara. Pamekasan pada 3 Agustus 2020.

Karim, Abdul. Wawancara. Bangkalan pada 27 Agustus 2020.

Nasrulloh. "Filantropi Islam: Praktek dan Kontribusinya terhadap Ketercapaian Sustainable Development Goals (SDGs)," Proceedings $3^{\text {rd }}$ Annual Conference for Muslim Scholars (AnCoMs) Kopertais Wilayah IV Surabaya, Volume 3, Nomor 1 (2019). 